\title{
Complete Ossification of the Superior Transverse Scapular Ligament in an Indian Male Adult
}

\author{
Osificación Competa del Ligamento Escapular Superior en un Hombre Adulto de la India
}

Mohd. Azim Khan

KHAN, M. A. Complete ossification of the superior transverse scapular ligament in an indian male adult. Int. J. Morphol., 24(2):195-196, 2006.

SUMMARY: Complete ossification of the superior transverse scapular ligament is generally considered to be rare and has not been previously described in an Indian. In the diagnosis of suprascapular nerve entrapment syndrome, variations in the anatomy of the superior transverse scapular ligament must be considered as possible etiologic factor, as illustrated by this case report.

KEY WORDS: Suprascapular ligament; Ossification; Entrapment syndrome.

\section{INTRODUCTION}

The documented variations of the superior transverse scapular ligament include calcification, partial or complete ossification and multiple bands (Ticker et al., 1998) In the diagnosis of suprascapular nerve entrapment syndrome, these variations in the anatomy of the superior transverse scapula ligament sometimes feature in the hierarchy of possible etiologic factors (Callahan et al., 1991). However, suprascapular nerve entrapment syndrome has also been described in clinical scenarios without a visible ossification of the superior transverse scapular ligament. Complete ossification of the superior transverse scapular ligament or suprascapular nerve entrapment syndrome has not been previously described amongst Indians. In this case report, I am describing completely ossified superior transverse scapular ligament in an adult Indian scapula.

\section{CASE REPORT}

During routine bone extraction from a male cadaver for our bone library, It was observed that the left superior transverse scapular ligament was completely ossified. The ligament stretched across the entire length of the suprascapular notch of the left scapula (Fig. 1). The superior maximal length was $0.9 \mathrm{~cm}$ long, while inferior maximal length was $0.5 \mathrm{~cm}$ long and the thickness was $0.5 \mathrm{~cm}$ long at medial end and $0.4 \mathrm{~cm}$ at lateral end of notch. The entire left scapula's dry weight was $78.5 \mathrm{~g}$.

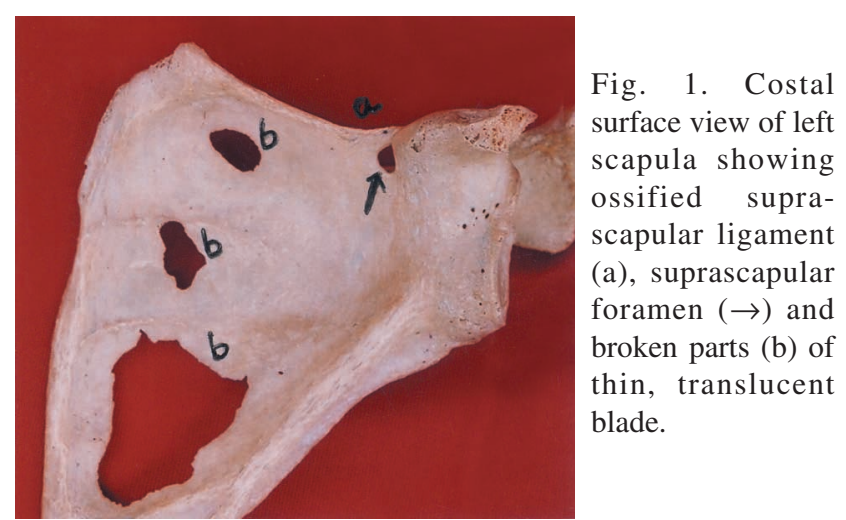

The left sided scapula observed in the present case was thickened at its three borders and at its two angles (lateral and superior) but was thinned out, translucent and weak at its inferior angle and at its rest of blade. The costal surface was concave, with three prominent ridges and was broken (Fig.1) at places during detachment of muscles. The upper border of the blade was nearly horizontal and continued with ossified superior transverse scapular ligament over suprascapular notch, converting it into suprascapular foramen and joined with the medial aspect of coracoid process (Fig 2).

The left scapular bone appeared normal in all other parameters. 


\section{DISCUSSION}

The suprascapular notch is frequently bridged by bone rather than a ligament, converting it into foramen in some animals. But in humans, the conversion of suprascapular notch into a foramen as a result of the ossification of the suprascapular ligament was found in three of 60(5\%) scapulae by Poirier \& Charpy (1911). In 133 finish scapulae studied by Kajava(1924), the foremen was present only twice $(1.5 \%)$. Vallois (1925) found the foramina to occur 13 times in 200(6.5\%) scapulae of Frenchmen. In a second study Vallois (1926) reported that Italian scapulae had foramina in $6.1 \%$ and in a series of scapulae from various sources the incidence varied from $0 \%$ to $3.3 \%$. Gray (1942) found foraemen in 73 of 1,151 scapulae $(6.34 \%)$ but no suprascapular foramina were found in 87 Indian scapulae. Cohen et al. (1997) described a familial case of calcification of superior transverse scapula ligament, affecting a 58 year old man and his son who had calcification of superior transverse scapular ligament, causing entrapment neuropathy of the suprascapular nerve and it attendant clinical symptoms of pain, weakness, atrophy of the supraspinatus muscle. Osuagwu et al. (2005), also reported a case of complete ossification of the superior transverse scapula ligament in a Nigerian male adult. There are descriptions in the literature of bifid (Alon et. al., 1998) and trifid (Ticker et al., 1998) superior transverse scapular ligament, with the former including an account of ensuing suprascapular nerve entrapment. Rengachary et al. (1979),

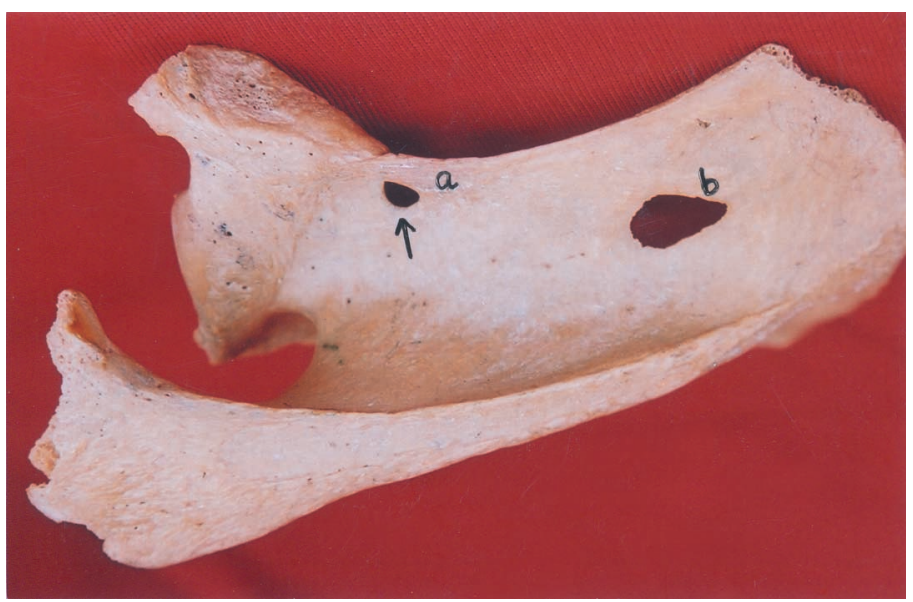

Fig. 2. Supero-posterior view of left scapula showing superior border, suprascapular ligament (a), suprascapular foramen $(\rightarrow)$ and broken hole (b).

have reported six different types of anatomical variations in suprascapular notch. They also reported that these anatomical variations of the suprascapular notch and superior transverse scapula ligament constitute potential predisposing factors to suprascapular nerve entrapment.

The present case report indicates that complete ossification of superior transverse scapular ligament can occur in Indian population as well and that, further studies are required to determine its frequency and significance in Indian adult. The present case report is also significant as such report in Indian population are not documented.

KHAN, M. A. Osificación completa del ligamento escapular superior en un hombre adulto de la India. Int. J. Morphol., 24(2):195-196, 2006.

RESUMEN: La osificación completa del ligamento escapular superior es generalmente considerada como rara y no ha sido descrita previamente en un indio. Variaciones anatómicas del ligamento escapular superior pueden ser consideradas en el diagnóstico del síndrome de compresión del nervio supraescapular, como posible factor etiológico, ilustrado en este caso.

PALABRAS CLAVE: Ligamento suprascapular; Osificación; Síndrome de compresión.

\section{REFERENCES}

Alon, M.; Weiss, S.; Fischel, B. \& Dekel, S. Bilateral suprascapular nerve entrapment syndrome due to anomalous transverse scapula ligament. Clin. Orthop., 234:31-3, 1998.

Callahan, J. D.; Scully, T. B.; Shapiro, S. A. \& Worth, R.M. suprascapular nerve entrapment. A series of 27 cases. J. Neurosurg., 74:893-6,1991.

Cohen, S. B.; Dnes,D.M.\& Moorman, C.T. Familial calcification of the superior transverse scapula ligament causing neuropathy. Clin. Orthop. Rel. Res., 334:131-5,1997.

Gray, D. J. Variations in the human scapulae. Am. J. Phys. Anthropol., 29:57-72, 1942

Kajava, Y. Uber den Schultergiirtel der Finen. Ann. Acad. Sci. Fenn, Series A., 21(5):1-69,1924.

Osuagwu, F. C; Inocemi, I. O. \& Shokunbi, M. T. Complete ossification of the superior transverse scapular ligament in a Nigerian male adult. Int. J. Morphol., 23(2):121-2, 2005.

Osuagwu, F.C.;Imosemi, I.O.\& Oladejo, O.W. Sources of cadaver used for dissection at the Ibadan Medical School, Nigeria - Analysis of a three year data. African J. Biomedical Research., 7:93-5,2004.
Poirer, P. \& Charpy, A. Traite d'Anatomic Humaine. 3. ed. Paris, 1911.

Rengachary, S. S.; Neff, J. P.; Singer, P. A. \& Brackett, C. F. Suprascapular nerve entrapment neuropathy: A clinical, anatomical and comparative study. Part 1. Clinical study Neuro surgery, 5:441-6, 1979.

Ticker, J. B.; Djurasovic, M.; Strauch, R. J.; April, E.W.; Pollock, R. G.; Flatow, E. L. \& Bigliani, L.U. The incidence of ganglion cysts and variations in anatomy along the course of the suprascapular nerve. $J$. Shoulder Elbow Surg., 7(5):472-8, 1998.

Vallois, H. V. L'os acromial dans les races humaine. L'Anthropologie, Paris, 35:977-1022, 1925.

Vallois, H.V. Variations de la cavite glenoide de L'omoplate. Soc. Biol. Comptes Rendus Hebdomadaires. Soc. Seances et inenoriores., 94:559-60, 1926.

Correspondence to:

Dr. Mohd. Azim Khan

65/B, Railway Tank Colony

Raibareli (U.P.) -229001 - I $\mathcal{L}(\mathcal{D} I \mathcal{A}$

E-Mail-drazim@rediffmail.com. 